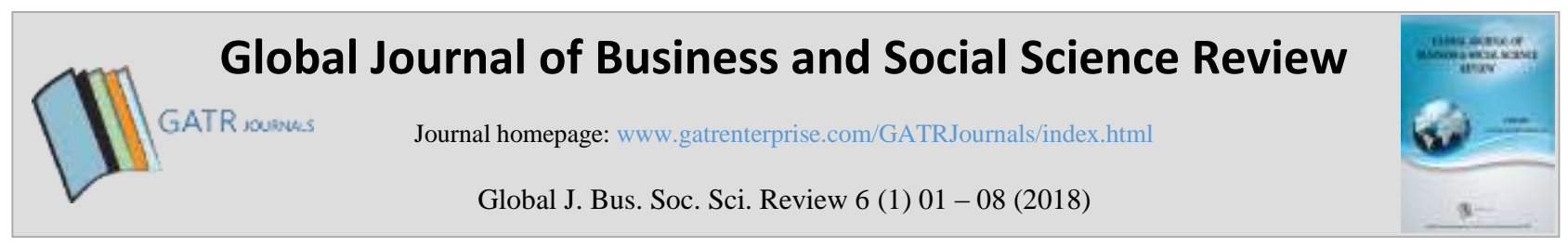

\title{
Social Capital, Migration, and Social Integration
}

\author{
Mai Le Thi ${ }^{1 *}$ \\ ${ }^{1}$ Sociology Department, Faculty of Social Sciences \& Humanities, \\ Ton Duc Thang University, Ho Chi Minh City, Vietnam
}

\begin{abstract}
Objective -This paper focuses on exploring the ways in which social capital is utilised to promote the integration of Vietnamese women who married Taiwanese husbands into host families and the host.

Methodology/Technique - Data was derived from a case study undertaken in 2014 on the Penghu Islands and in Taipei, Taiwan, with interviews and the observation of 31 people including Vietnamese women who married Taiwanese husbands, local people.

Findings - Findings reveal the values and norms of responsibility of Vietnamese women in family that were educated themselves, have been practiced effectively by Vietnamese women married to Taiwanese husbands to integrate into their families.

Research limitations/implications - The regulations and legal environment for immigrants have created favourable conditions for their integration into the host families. Traditional Vietnamese cooking skills are chosen by many Vietnamese women as a kind of social capital for their access to the Taiwanese job market. The social integration is reflected through social-economic, culture integration, and citizenship.

Originality/value - It is hoped that study results will serve as the useful scientific basis for developing policies that promote the social integration of immigrants for the development of individuals and the social community.
\end{abstract}

Type of Paper: Empirical

Keywords: Social Capital; Social Integration; Migration Marriage.

JEL Classification: C31, O15

\section{Introduction}

The phenomenon of young rural women of the Mekong Delta, Vietnam, marrying foreigners, mostly from Taiwan and South Korea, began in the 1990s when the 'Doi Moi' economic reforms opened Vietnam to attract foreign direct investment capital and has become a feature for integration of the Vietnamese into the global community. This phenomenon has been developing over the past 30 years since the 1990s. More than two generations of these transnational marriages have been taking place in Taiwan.

Paper Info: Revised: December, 17, 2017

Accepted: February, 18, 2018

* Corresponding author:

E-mail: lethimai52@gmail.com

Affiliation: Ton Duc Thang University, Ho Chi Minh City, Vietnam 
According to the statistics from Department of Household Registration Ministry of Interior (M.O.I, 2103), among the total number of naturalized spouses from Southeastern Asian countries, Vietnamese spouses account for almost 77\% (YU Teng-Huang, 2014, p. 21). As former Minister of M.O.I., Lee Hong-Yuan said, the rise in the divorce rate, $2.41 \%$ in 2013 , the third highest in the world, could partly be ascribed to the increasing number of transnational marriages in Taiwan because a great number of foreign spouses either from Mainland China or Southeast Asian countries often have a hard time adapting to the Taiwanese culture, leading to a high divorce rate among transnational couples (Wu, 2013; YU Teng-Huang, 2014). The important issue with regard to this research is to understand how immigrants integrate into the Taiwanese country. This paper analyses the ways in which social capital is utilised to promote the integration of Vietnamese women married to Taiwanese husbands into host families and the Taiwanese country and as well as the programs created for the sake of empowerment and education that focus on providing these marriage immigrants with better opportunities.

Utilizing a variety of sources, we were able to identify the courses in which social capital have been found to advance or upset joining of Vietnamese mates into their significant others' families in Taiwan. The topics found in the literature include the concepts of social capital and social integration, the role of social capital in social and economic integration, the influence of the host language proficiencies and inter-ethnic contact in neighbourhoods on building social capital, and ways in which policy and legislative contexts affect the development of social capital and facilitate immigrants' social integration.

Social capital is a concept that has been defined and analyzed systematically by scholars (Bourdieu, 1986; Coleman, 1990; Bourdieu and Wacquant, 1992; Portes, 1998; Burt, 1997; Alberto Palloni, et al., 2001). Coleman (1990, p.305) analyzed the role of social capital in migrant integration as 'resources that can be used by the actors to realise their interests'. An individual can mobilise the social capital embedded within social ties to gain valuable information, moral support, and material assistance. (Gunawan Prayitno, et al., 2014).

Social integration is defined as the harmonious and coherent processes of the structure of a social system (Koramaz, 2014) and as the stability of relations among parts within a system as a whole (Le, 2014). Social integration is also further developed as structural integration, cultural integration, interactive integration, and identification integration (Bosswick \& Heckmann, 2006). This paper concerns with understandings of the socialization of immigrant women, specifically those married to Vietnamese spouses who immigrated to Taiwan. The existing research outlined aims to illustrate, support, and query the findings.

\section{Methods}

\subsection{Methodology}

This study was guided by a qualitative methodology with in-depth interviews, group discussions, and participant observations. It was conducted by observing the informants' activities, participating in their normal life and listening to their stories, organising some travels, having lunch in their restaurants, or visiting their homes in the evenings whenever permitted. The average two-hour in-depth interview was performed in Vietnamese. Some informants were interviewed several times due to the need for more information and for exploring the new themes noticed from previous interviews. An additional semi-structured interview was used also to interview some related parties, such as the husbands, neighbours, or villagers, to collect data during visiting their homes. Working networks involving lecturers and researchers in National Penghu University (NPU) and the Vietnamese students who were studying in NPU, Mango, the Penghu Islands, and Taiwan had been useful resources for carrying out these works. 


\subsection{Recruitment of informants and sampling methods}

Informants were recruited from the introduction of our Vietnamese students who were studying at National Penghu University (NPU) in the Penghu Islands and National Cultural University in Yang-MingShan, Taipei, Taiwan. A snowball sampling method was developed to trace the social networks of the informants and to find new interviewees of which 26 informants were met through this method. Five interviewees were met randomly in the fieldwork. These 31 Vietnamese women were identified as the key informants. The selection criteria of these informants included all informants involved in TaiwaneseVietnamese marriages including those coming from different social backgrounds and married to Taiwanese husbands after the 'Doi moi' period. "Doi moi" (Renovation in English) is name given to the economic reforms in initiated in Vietnam 1986 with new policies including one of attracting foreigner investment in the 1990s. These standards were considered important because it not only symbolised globalization but also the beginning of rapid social changes in Vietnam.

\subsection{Profile of research participants}

The maximum variation of data was also given attention in our consideration, and it aims to select cases that provide for wide variations in the experience or processes being examined. Various attributes such as age (from 25 to 46 years old), educational level (from primary school to the student of the university), social class (up to middle class), and occupation before marriage were taken into account and also identified as important factors. Consent for interview and recording of informants were obtained after the research topic and purpose were introduced.

\subsection{Terminology}

This paper employs Coleman's definition of Social capital as constituting 'resources that can be used by the actors to realise their interests' (Coleman, 1990, p. 305). The social capital of Vietnamese marriage immigrants is identified using two dichotomy categories: individual/cognitive social capital and structural one. Their individual social capital was examined by the filial daughters socialised in Vietnam as traditional cooking skills, the ability to take care of all members of the family, especially children, obedience to the mother-in-law, being responsible to both natal family and husband's family, faithfulness, honesty, diligence about earning money, tolerance to hardships, and proficiency in Mandarin before marriage. Their structural social capital was examined by interviewing daughters of shared origins, casual friends, acquaintances, even friends of friends who had married Taiwanese husbands prior to moving to Taiwan. We also analysed Taiwanese governmental procedures and regulations that would create favourable conditions for integrating them into the host families, such as availability of Mandarin language courses and vocational courses before they would start a small business or work from anywhere. Social integration is reflected in the legal and stability relationships of migrant wives with their husbands' families and by their access to the labour market and civil society activities as a whole.

\subsection{Theoretical Approach}

Social network analysis was used to show how Vietnamese immigrant spouses took advantage of relationships, experiences, and opportunities to empower themselves to access social integration and achieve their goals. Vietnamese immigrant spouses have access to social resources and support such as courses for learning the Mandarin language and other training courses that the Taiwanese government opened up for them to improve their capacity. These endeavours also enabled Vietnamese spouses to access the labour market and participate in social activities. The sustainable livelihood approach was used to analyse the reasons why the majority of rural women in South Vietnam choose marriage to foreign husbands as a 
strategy to escape poverty, get the financial capacity of their own to support Vietnamese natal families, increase their social mobility, and ascend to a higher social class. (Le, et al., 2017, p. 63-64).

\subsection{Data}

Data was mainly derived from interviews and observations conducted in 2014, from 31 marriages between Vietnamese immigrant women and Taiwanese men between the periods of 1990-2014 who have been living in the Penghu or Pescadores Islands and Taipei, Taiwan for at least 5 years. This investigation was ethnographic in approach, involving months of intensive participant-observation and active participation in community activities involving members from transnational marriage families. Connections were continued by mobile phone, face-to-face interviews whenever they came back Vietnam to visit their native families.

\section{Results and Discussion}

3.1 Finding 1. The values and norms of responsibility of women in the family had been developed and practiced effectively by Vietnamese women married to Taiwanese husbands to integrate into their family.

Finding confidence within the husband's family wasn't always easy for Vietnamese women and chiefly depended on the woman herself. Information from group discussions conducted in Magong City, on the Penghu Islands, revealed presence of the initial difficulties associated with building these relationships. It was reported that, during the first period of adjustment, Vietnamese spouses tried their hardest to satisfy their husbands and their family members by responding to their expectations.

.... I was so sad and homesick. My husband is very gentle. His family once had a fishing boat and now he works as a wall-paint man. My "mother-in-law" was old and too sick to go. I woke up at 6 am daily to cook vegetarian food for the mother-in-law to eat, cook porridge, cook food for all meanwhile I was suffering from vomiting by being pregnant. I took care of mother-in-law from my heart. She was very gentle and loved me too. (49 years old, Phu Yen province, the Middle Vietnam)

My chances are here. It is too poor to be a farmer, so many poor rural girls like us without much education and skills have preferred to being an immigrant spouse. It all depends on how well I meet my husband family's expectations for a daughter-in-law. I have known the marriages of some Vietnamese spouses are unsuccessful, not as they expected. Most of them sacrifice and suffer for the happiness of their children. In case of divorce, they try to fulfil the responsibility of caring for children and meet the conditions for their children to go to good quality schools. "Do it all for our children" is a statement that is often heard (46 years old, Saigon City).

The informants had expressed different thoughts and ideas on daughters' filial roles. Some viewed 'sending money back home' was important for them due to the feelings of guilt associated with their absence from physical care of parents. They wanted to remit money to their natal parents as a form of compensation. The money sent home served as an indication of their financial capability and a means of improving their status at home as well. They had associated the act of sending money home with the 'face' issue. At the same time, with the remittances from the migrant daughters, the parents and siblings also gained more chances of achieving some changes. Reciprocally, they would help to increase their daughters' status in their husbands' families. Following are their voices from a group discussion in Penghu Islands: 'I give money to my parents... just want to show my small gratitude, reducing my worry' (36 years old, Quang Ninh province, the North Vietnam). 'By giving money, I also want them to know that my life is good' (33 years old, Dong Nai province, the South Vietnam). 'My parent's house is built by my remittance for 3 years. They are proud of me. Villagers often conversed with my mother "Your daughter is so filial". Of course, there are also spouses who cannot make any contribution. People around will spread the gossip like "she has married a terrible guy" 
or "she has been trafficked into prostitution". The parents will also lose 'face' (46 years old, Can Tho province, Vietnam). 'I sent money to both my parent and parent-in-law monthly. My husband is starting to believe in me. My business runs effectively due to the support of my husband's family' (49 years old, Phu Yen province, the Middle Vietnam).

3.2 Finding 2. The regulations and legal environment for immigrants, Vietnamese immigrant spouse network were considered as dimensions of structural social capital that had created affiliated conditions for their integration. The social integration was reflected through citizenship as well as social-economic and culture integration.

Under the provisions of the Taiwan Government, Vietnamese wives who first arrived in Taiwan had to apply for a temporary residence registration to be immediately signed by their Taiwanese husbands who were acting as their guarantors. Vietnamese spouses often enrolled in Mandarin language classes organised by local authorities to support them. A Vietnamese lady teaching in these classes explained:

There were classes for Vietnam spouses. They teach two languages as Vietnamese-Mandarin or Mandarin-Vietnamese. I completed that course and was granted Certification. Now I am an enrichment teacher of Vietnamese to children and adults here.

A 36-year-old Vietnamese spouse from Long An province said:

I am now studying interpreting classes, yoga classes. Monthly an afternoon meeting held for the Vietnamese spouses clustered talking, eating, and drinking together. Participating meetings makes me happy and reduces my homesick. We exchange with each other about work, family life, and especially happy if someone returns to Taiwan after a visiting native family, there are many things to say.

Voices from Vietnamese spouses themselves reflected that the local government has not only created a useful legal environment but also organised activities to cater to their other needs that facilitates them to integrate into society. In a group discussion, a woman of 38 years old from Soc Trang province of Vietnam said:

My village was named "Taiwan Island" because roughly 90\% its daughters married Taiwan husbands. We have each other's phone numbers to contact. We often inform each other of new government regulations ...

Another Vietnamese spouse of 36 years old, from Quang Ninh province said:

I did not know how to read Mandarin, just say a few sentences. Since going to the class of Mandarin, I feel comfortable and confident in communication with my husband, other family members, and neighbours. After 3 years, I was granted ID by local authorities. I studied a vocational training course and now am a worker in a seafood processing facility.

A Vietnamese spouse of 49 years old, coming Taiwan from Phu Yen province said:

Most of rural Western Mekong Delta women married Taiwanese in Penghu. I helped some women so that they were eligible for ID. I got some women to work in my restaurant when they have not found suitable jobs yet... With the support of local authorities, I am mobilizing Vietnamese spouses participating community activities to meet the requirements of local government for establishing the Vietnamese Association in Penghu. Lecturers at the National Penghu University are very enthusiastic in teaching classes for foreign women marrying Taiwanese. These short-term classes provide the basic knowledge necessary for those who want to go to work.

The economic incorporation of Vietnamese immigrant spouses provided a useful illustration of whether immigrant networks could be beneficial for them. Along the street 111 Taiwan Taipei city, Shihlin District, Dexing East Road, there were 10 food outlets/restaurants (2014), of which about 50\% were owned by Vietnamese immigrant spouses. Employers often helped newcomers by getting them to work for a living. Each month, they earned about 21 thousand Yuan, working from 8 to 10 hours per day. Customers were both Vietnamese and local people. They came here to eat Vietnamese dishes and to meet and communicate with each other about the experiences of success and failure. This evidence illustrates the way in which 
immigrants used their social networks and co-ethnic social capital to participate in labour markets. Niche employment in retail, restaurants, and nail shop were common among Vietnamese immigrants spouses.

\subsection{Finding 3. Traditional Vietnamese cooking skills were chosen first by many Vietnamese immigrant spouses for their access to the Taiwanese job market, even for social mobility.}

Out of the 31 informants, 17 considered their earning ability had increased after their marriages. Job opportunities in Taiwan came more easily regardless of their socio-economic backgrounds, and they were able to find work in spite of being limited in skills and education. However, they all talked about the opportunities brought by mobility with what were socialised in Vietnam. Vietnamese immigrant spouses began running their own businesses in order to build up both their financial basis to send more money back to their natal families as well to elevate their social statuses from within Taiwan. Following is the story of Vietnamese immigrant spouse as a case:

I was born in Phu Yen province. Then, I and my family migrated to Saigon and traded. I was used to running a business of video cafes. Because of the sad love story, then I got married to Taiwanese man by my friend's introduction. His family was so poor. My mother-in-law was sick. I alone had to take care daily for 4 children ( 2 of mine and 2 of husband's younger sister) and an elderly in the big family. After the death of mother-in-law, we had no money, we were bickering each other daily and I decided to go outside to work. I worked all day for earning only 8,000 Yuan. Finally, I called back my older brother in Vietnam to learn how to cook "Pho"-a kind of Vietnamese traditional beef noodle for sale. The "Pho" is cooked quality, customers like them, they go online advertising it... I have some acquaintances as the lecturers in National Penghu University (NPU) and whenever the school has any activities, I go there to cook or make Vietnamese dishes and invite them to eat and to advertise as well. Students and teachers there also advertised it. Taiwanese guests write multiple postings... My son is in 9th grade and my daughter is in 7th grade. What I possess today, besides my own efforts, results from the help of the kind-hearted Taiwanese, from the local government. Now I am focusing on fulfilling the conditions for the establishment of the Vietnamese Women's Union in Penghu. (49 years old, Phu Yen province, the Middle Vietnam)

'Capable' was a word often heard about Vietnamese spouses and was associated with a Vietnamese spouse's ability to make money. Although not all spouses had professional training, they found means of earning more money. They had been aware of the opportunities brought by practice social capital for their access to the Taiwanese job market.

Contrary to the most of the results that explored in last researchers, findings in this case study have shown that what Vietnamese immigrant spouses who participated in this study need is a chance to create a change for their better life by their own capacity. A transnational marriage was chosen as a means of attaining better opportunities. During the fieldwork, we found that informants became more talkative and comfortable after having met several of them together in their familiar environment. The Vietnam Pho Restaurant run by a Vietnamese spouse from Ho Chi Minh City near 北辰市場 (Beichen) Market was a place for many Vietnamese spouses to hold regular or occasional parties and gatherings and exchange gossip. These events were good opportunities for us to make participant observations and to hear different voices and stories from them.

Pieces of evidence from this study reflected Vietnamese immigrant spouses' acumen in taking advantage of social capital that was socialised both in Vietnam as well as in Taiwan and negotiating difficulties to integrate with the host families. According to research results, about $80 \%$ of marriages between poor rural women and Taiwanese men in the Mekong Delta, Vietnam were motivated by economic considerations. (Park, 2012; An, 2011; Nguyen, 2010; Le, 2017). In public opinion then, Vietnamese spouses are often viewed as pragmatic women who care only about money rather than love. If so, why would the majority of them get married to poor rural Taiwanese men? Evidences from this study showed that they are smart and 
care a lot about filial daughters and self-development. Above all, they can adapt to the Taiwanese culture and perform their traditional roles in marriage to serve their ends. What 'Vietnamese spouses' care about is not only money but grasping possible chances for better life and happy marriage as they expected.

The findings helped us gain more insight into the new social networks constructed by Vietnamese spouses from the dynamic of self-empowerment through working or running their own businesses in the host society and by creating a wide variety of interactions with the locals. Conversations revealed presence of a strong desire for development. Efforts to overcome the difficulties and differences to integrate into the Taiwanese society of Vietnamese immigrant spouses have been the source of inspiration of films and reporters. An immigrant's lack of citizenship may limit Vietnamese immigrant's spouse's access to destination-country institutions and organizations. This limitation then would be addressed by government interventions in the capacity building for immigrants. These are suggestions for extending further research issues to further promote the level of social integration of immigrants, thereby increasing their contribution to socialeconomic development of the host society.

\section{Acknowledgements}

This research has been funded by The Foundation for Science and Technology Development of Ton Duc Thang University (FOSTECT), website: http://fostect.tdt.edu.vn, under Grant FOSTECT.2015.BR.21. I would like to extend my gratitude to those Vietnamese women married Taiwanese men who had agreed to participate in this survey. I would also like to thank our graduate students and colleagues in Taiwan for their help. Without their enthusiastic and effective cooperation, we could not carry out this study. We would like to express our sincere thanks to Dr. Dominic Hewson, an Irish colleague for English language editing of this article. I appreciate and thank the Global Journal of Business and Social Science Review (C) 2018 Global Academy of Training \& Research (GATR) Enterprise, for the publication of our first article based on the results of research in Taiwan. It has encouraged me to continue to develop, extending the results in this article.

\section{References}

Alberto Palloni, A., Massey, D. S., Ceballos, M., Espinosa, K., \& Spittel, M. (2001). Social capital and international migration: A test using information on family networks. American Journal of Sociology, 106(5), 1262-1298.

Heckmann, F., \& Bosswick, W. (2006). Integration of migrants: Contribution of local and regional authorities.

Bourdieu, P., \& Wacquant, L. J. (1992). An invitation to reflexive sociology. University of Chicago press.

Bourdieu, P. (1986). The forms of capital»: 241-258. Teoksessa Richardson.

Burt, R. S. (1997). The Contingent Value of Social Capital, Administrative Science Quaterly 42 (2): 339-365. CrossRef Google Scholar.

Coleman, J.S. (1990). Foundations of Social Theory. Cambridge: Harvard University Press.

Prayitno, G., Matsushima, K., Jeong, H., \& Kobayashi, K. (2014). Social capital and migration in rural area development. Procedia Environmental Sciences, 20, 543-552.

Koramaz, E. K. (2014). The spatial context of social integration. Social indicators research, 119(1), 49-71.

Le, T. M. (2014). Social Integration of Vietnamese People Residing Abroad. International Conference Proceedings. ISBN: 978-969-9948-01-5. P. 534-577. INTERNATIONAL CONFERENCE ON Global Trends in Academic Research - GTAR-2014. June 2-3 2014. Bali Indonesia. Retrieved from http://www.globalilluminators.org/wpcontent/uploads/2014/09/409.pdf.

Mai, L. T. (2017). Social Integration of Vietnamese Women Married to Foreigners (Case Study in Penghu Islands and Taipei, Taiwan). Global Academy of Training and Research (GATR) Enterprise.

Nguyen, N.N.A. (2010). Current Issues of Marriage Migration in Vietnam. Paper presented the 2010 ARENA International Workshop "From Individual to Community: On Reinterpreting Citizenship \& Asian Marriage Migration" organized by Asian Regional Exchange for New Alternatives, Pusan, Korean. 4-5 June 2010. Park, S. H. The Cognition 
of Vietnamese Woman Marriage Migrants on the Economic Condition Change Before and After Marriage. Magazine of Korean Local Geographic Learning. Volume 18, No. 3.

Phan, An. (2011). "Hôn nhân xuyên quốc gia: Trường hợp lấy chồng Đài Loan và Hàn Quốc ở Đồng bằng Sông Cửu Long. Tổng luận nhân văn. Viện nghiên cứu Khoa học Nhân văn. Trường Đại học nữ Seoul. Số 23. ("Transnational Marriage: Case of getting married Taiwan and South Korea Husbands in the Mekong Delta. Summa Humanities. Research Institute of Human Sciences. Seoul Women's University. No. 23).

Portes, A. (1998). Social capital: Its origins and applications in modern sociology. Annual review of sociology, 24(1), $1-24$.

Wu. S. (2013). Talk of the Day - Transnational Marriages and Divorce Rate. Central News Agency. 2013-08-26.

Retrieved from http://www.taiwannews.com.tw/etn/news_content.php?id=2287379

YU, T. H. (2014). Vietnamese Spouses' Cultural and Social Identity in Taiwan. 